\title{
Zločinačka narav komunizma
}

JURE KRIŠTO

Zagreb

E-pošta: jukristo@gmail.com
UDK: 329.15(091)"191/198" 321.64(091)"191/198"

Pregledni rad

Primljeno: 26. ožujka 2019. Prihvaćeno: 21. svibnja 2019.

\section{Sažetak}

Središnja preokupacija komunističkih vođa jest revolucija, mržnja i osveta, uz lažno obećanje promijenjenih i poboljšanih uvjeta života. Stoga komunizam proizvodi smrt i obiluje zločinima, jer je u svojoj biti okrenut prema zlu. On je također sustav osmišljen za ekstremnu kontrolu ljudskoga duha i propisivanja načina mišljenja. Dolaskom na vlast u Hrvatskoj i Bosni i Hercegovini, komunisti su ponovili sve ono što su njihovi uzori, od Lenjina do Staljina ranije radili u carskoj Rusiji i od 1922. u Savezu Sovjetskih Socijalističkih Republika (SSSR). Katolička Crkva posvećuje posebnu pozornost žrtvama toga bezbožnog, nehumanog i protucivilizacijskog sustava i njihovu žrtvu želi istaknuti kao svjedočenje za Boga, vjeru, osobne ideale, zajedništvo svetih i kao zalog za stvarnu bolju budućnost svijeta.

Ključne riječi: komunizam; ideologija, klase; zločini; mržnja na vjeru; progoni; Crkva; žrtve; mučenici. 


\section{Uvod}

Hrvati su svjesni činjenice da su komunisti koji su predvodili partizane tijekom borbi za osvajanje vlasti i još više nakon pobjede u ratu počinili mnogobrojne zločine nad suprotstavljenim vojnicima i civilima. Nisu Hrvati u tome iznimka, jer je to iskustvo i mnogih drugih naroda koji su došli pod komunističku vlast. No, ono što nas ovdje zanima može se izraziti u dva pitanja. Prvo, ima li u marksističkoj/ komunističkoj ideologiji ičega što je nužno usmjereno na činjenje zločina, na proizvodnju žrtava? Drugo, s obzirom da su vjernici bili osobita meta komunističkoga nasilja, jesu li zločini nad vjernicima plod osobite mržnje na vjeru? Ako je odgovor na drugo pitanje potvrdan, postoji visok stupanj vjerojatnosti da je među mnogobrojnim žrtvama toga sustava bilo svjedoka kršćanske vjere, tj. mučenika.

\section{Bitne teze komunizma}

Otac marksizma ${ }^{1}$ bio je Karl Marx (1818. - 1883.), koji zbog svoga židovskoga podrijetla nije u Njemačkoj mogao postati profesor filozofije, pa je postao novinar. $U$ vidu posebna pogleda na svijet napisao je svoje glavno djelo Das Kapital (1867.). Bila je to, kako je u podnaslovu naznačeno, "Kritika političke ekonomije", zamišljene u tri sveska, od kojih je Marx izdao samo prvi, a njegov prijatelj Friedrich Engels (1820. - 1895.) posthumno izdao je druga dva (1883.). Tijekom boljševičke revolucije u Rusiji i nakon uspostave boljševičkoga sustava, njezin vođa Vladimir Iljič Uljanov (1870. - 1924.), poznatiji pod pseudonimom Lenjin, unio je neke novìne u marksističku teoriju, tako da se komunizam od tada identificira kao marksizam-lenjinizam.

Temeljne postavke marksističke filozofije proizvod su dvaju pristupa - dijalektičkoga i historijskoga materijalizma. Očito je da je temeljna postavka Marxove filozofije materijalizam. Zbog toga u njegovu

1 O marksizmu postoji, dakako, preobilna literatura, kao što postoji i obilje interpretacijskih modela njegove filozofije i povijesne uloge. Za potrebe ovoga članka usredotočio sam se na kratki sažetak najvažnijih ideoloških postavki te na posljedice koje iz toga proizlaze. Za malo sustavniju, ali ipak kratku, prezentaciju toga, vidi: J. KRIŠTo, "Komunizam kao ideologija i politički program", u: Mile Bogović - Josip Dukić - Jure Krišto - Mate Rupić - Miljenko Stojić (ur.), Hrvatski mučenici i žrtve iz vremena komunističke vladavine. Zbornik radova s međunarodnoga znanstvenog skupa održanog u Zagrebu 24. i 25. travnja 2012., Glas Koncila, Zagreb, 2013., str. 40-58. 
obzorju nije bilo ni metafizike ni spekulativne filozofije, nego samo usredotočenost na empiriju. ${ }^{2}$

Marx, međutim, i svoj materijalizam promatra u dijalektičkom procesu. Materija je podložna uzročnim i determinističkim zakonima, ali posjeduje više od mehanističkih kvaliteta. Materija se razvija u sve kompleksnije oblike koji u određenome trenutku nakon napetosti i sukoba prelazi u kvalitativno drukčiji oblik. Materija je tako slična društvu koje također unutarnje suprotnosti i sukobe razrješuje revolucionarnim skokovima. ${ }^{3}$

S obzirom na te temeljne pretpostavke, Marx je bio protivnik svakoga oblika religije ili nadnaravnosti. Drugim riječima, jedna od bitnih karakteristika marksizma jest ateizam. Sa sigurnošću se može reći da je Marx najprije bio ateist, a potom analitičar društva. ${ }^{4}$ Marxov ateizam nije plod racionalnoga razmišljanja ili filozofskoga sustava, nego apriorni stav da religija, Bog, zagrobni život, raj i pakao ne mogu biti racionalno opravdani. Oni su proizvodi društvenih nepravednih odnosa i nužno će nestati kada se društveni odnosi promijene. ${ }^{5}$ Ideja o Bogu i religija u temelju su čovjekova samo-otuđenja; tek će kasnije Marx ustvrditi da je privatno vlasništvo čovjekovo temeljno otuđenje koje uvjetuje i otuđenje u religiji i Bogu. Marx je svoje shvaćanje religije sažeo u često citirani - i nerijetko pogrješno razumljeni - slogan: "Religija je uzdah potlačenog stvorenja, duša nesmiljena svijeta, kao što je i duh bezdušnih prilika. Ona je opijum naroda". ${ }^{6}$

Možda su u Marxovu sustavu važniji rezultati historijskoga materijalizma. U vremenu u kojem je živio nije mu bilo teško uvidjeti da postoje sustavni, inherentni uzroci nepravde i korupcije u društvu. Njegov prijatelj, vlasnik tekstilnih tvornica Friedrich Engels u svome djelu Položaj radničke klase u Engleskoj (1884.) detaljno je opisao svu bijedu tvorničkih radnika (proletera). U kratkome nacrtu obrisa budućega komunističkog društva Manifest komunističke partije

2 H. B. Acton, "Dialectical Materialism", u: The Encyclopedia of Philosophy, sv. 1 i 2, New York, 1967., str. 389-397 (389).

3 Neil Mcinnes, "Marxist Philosophy", u: The Encyclopedia of Philosophy, sv. 5 i 6, New York, 1967., str. 174.

4 Jacques Maritain, Cjeloviti humanizam, Zagreb, 1989., str. 53, bilj. 1.

5 N. Mcinnes, "Marxist Philosophy", str. 173-176 (174).

6 Karl Marx, "Prilog kritici Hegelove filozofije prava", u: Karl Marx - FrieDRICH ENGELS, Rani radovi (ur. Predrag Vranicki), Zagreb, ${ }^{9}$ 1989., str. 90-134 (91). 
(1848.) za potrebe grupice Komunistička liga, Marx i Engels opisali su kapitalizam kao sustav gospodarenja u kojemu je jedna klasa - "buržoazija" - vlasnik sredstava za proizvodnju, dok je radnička klasa - "proletarijat" - samo dodatak stroju i predmet eksploatiranja. ${ }^{7}$ Buržoazija zadržava svu moć i svu vlast u društvu sredstvima osobite ideologije, izgrađene tako da služi interesima vladajuće klase. Problem s ideologijom je taj da i izrabljivani radnici postanu uvjereni u ono što mu ona posreduje i da misle da su takvi odnosi dobri i nepromjenjivi (to je, po Marxu, "pogrješna svijest").

Religija je, smatrao je Marx, jedan od moćnih sredstava posredovanja te svijesti; religija je ta koja "opija čovjeka", jer ga poučava da je njegovo stanje Božja volja. Marksisti su vjerovali da je Marx prozreo u bit svakog idealizma, uključujući i religijski: "Marx je dao teorijsku osnovu, da se konačno skine tajna s toga izvora duhovnih i materijalnih profita svih vrsta idealizama i religija. Ako se čovjekovo mišljenje razvija u suglasnosti s njegovim praktičkim preobražavanjem prirodne i društvene stvarnosti, onda je čovjek sam i stvaralac sama sebe. Najviši oblik postojanja prirode ima konkretno objašnjenje u ljudskoj praksi". ${ }^{8}$

Da bi se ta svijest i s njome stanje proletarijata promijenilo, sredstva za industrijsku proizvodnju moraju prijeći iz ruku pojedinaca u kolektivno vlasništvo, kako bi koristilo svima, tj. u prvome koraku u vlasništvo države. ${ }^{9}$

Da bi se, pak, sve to ostvarilo, nužno je da proletarijat svrgne buržoaziju s vlasti i tako kapitalizam ustupi mjesto komunizmu. Po sebi je razumljivo da se tako velik društveni obrat ne može dogoditi redovitim putem, sredstvima koja su do tada bila poznata i primjenjivana u svijetu, nego se moraju primijeniti izvanredna sredstva, a to je revolucija, nasilje. To je bit komunističke ideje "klasne borbe". On zapravo znači da je svijet, društvo "zasnovano na nasilju". Buržoazija nasilno drži proletarijat pod kontrolom, a potonji se može osloboditi samo nasiljem, tj. revolucijom. ${ }^{10} \mathrm{U}$ tom smislu Marx i Engels bili su

7 Komunistički manifest, August Cesarec, Zagreb, 1972.

8 Predrag Vranicki, "Predgovor prvom izdanju", u: Karl Marx - Friedrich ENGELs, Rani radovi, Naprijed, Zagreb, ${ }^{9} 1989$., str. 5-38 (28).

9 Encyclopoedia britannica, http://www.britannica.com/EBchecked/topic/129104/ communism (23. 2. 2012.).

10 Uputa o nekim aspektima "Teologije oslobođenja", Kršćanska sadašnjost, Zagreb, ${ }^{3} 2003$., str. 31. 
izravni: "Komunisti s prezirom odbijaju prikrivati svoje poglede i namjere. Oni otvoreno izjavljuju da se njihovi ciljevi mogu postići samo nasilnim obaranjem čitavog dosadašnjeg društvenog poretka. Neka vladajuće klase drhte pred komunističkom revolucijom. U njoj proleteri nemaju izgubiti ništa osim svojih okova. A imaju dobiti čitav svijet."11 Lenjin već 1914. piše: "Suština naše zadaće jest (...) težnja za preoblikovanjem rata u građanski rat", koji je i sam samo "produžetak, razvitak i prirodno naglašavanje rata među klasama". ${ }^{12}$ Lenjin je to primijenio u odnosu na bogate seljake (kulake) u ruskoj revoluciji kada je upućivao: "Treba da služite kao primjer, 1) Objesiti (kažem objesiti tako da ljudi to vide) najmanje 100 kulaka, bogataša, poznatih krvopija; 2) Objaviti njihova imena; 3) Dočepati se svega njihova žita; 4) Identificirati taoce, kao što smo to naznačili u jučerašnjem brzojavu. Učinite to tako da na okolnih stotinu milja ljudi vide, drhte, znaju i da sebi kažu oni ubijaju i nastavit će ubijati kulake žedne krvi. Pošaljite mi brzojav da ste primili i izvršili ove instrukcije. Vaš Lenjin. PS. Nađite najokrutnije ljude".13

Iako se, dakle, marksizam može promatrati kao svojevrsni napor za mijenjanje svijeta, štoviše za razrješenje nekih njegovih nedostataka, poput nemogućih uvjeta radničkoga života, to je pokušaj na apsolutan način - putem uništenja uzročnika zla u svijetu. Zato je nasilje logična posljedica temeljnih pretpostavka komunističke ideologije. Ne čudi stoga da su već Lenjin i Lav Davidovič Bronstein, također poznatiji po pseudonimu Trocki (1879. - 1940.) uveli pojam "klasnoga rata" kao permanentne revolucije. ${ }^{14} \mathrm{U}$ tom projektu proleterske revolucije ne postoji dvojba o tome da klasni neprijatelj mora biti uništen, jedino legitimno pitanje komunističkih revolucija jest koje sve skupine treba uvrstiti u klasne neprijatelje. Glavni nositelji "buržoazije", tj. vlasnici sredstava za proizvodnju, po definiciji su klasni neprijatelji, ali revolucija je definirala i druge društvene skupine klasnim neprijateljima, poput bogatijih seljaka ("kulaci"), svećenika i drugih predstavnika vjerskih organizacija ili Crkava ("popovi") i čla-

11 Karl Marx - Friedrich Engels, Manifest komunističke partije, Marksistički centar, Split, ${ }^{2} 1975$.

12 Citirano u: Alain de Benoist, Komunizam i nacizam. 25 ogleda o totalitarizmu u XX. stoljeću (1917. - 1989.), Zagreb, 2005., str. 42.

13 Nicolas Werth, "Država protiv svojeg naroda. Nasilja, represije, teror u Sovjetskom Savezu", u: Crna knjiga komunizma - zločini, teror, represija, Zagreb, 1999., str. 40-279 (80); autor se referira na Državni arhiv Ruske Federacije.

14 Isto, str. 286. 
nova vjerskih skupina koji su odaniji pregaoci za vjeru ("klerikalci") te veletrgovaca, trgovaca i kamatara (Źidovi). Sve te zasebne skupine svrstane su u kategoriju "narodnih neprijatelja". Čak su i neki narodi bili označeni kao po naravi proturevolucionarnima, primjerice Kozaci $^{15}$ i Hrvati. ${ }^{16}$

Lenjin, koji je pripadao revolucionarnome krilu - Boljševicima Ruske socijalno-demokratske radničke stranke, nije se slagao s Marxom da će se revolucija dogoditi spontano. U knjizi iz 1902. Što činiti? (Čto delat'), Lenjin je naučavao da revoluciju treba poticati, a nju bi morala predvoditi partijska avangarda radikaliziranih intelektualaca. Lenjin nije imao povjerenja u radničku klasu i u njezinu sposobnost da revolucionarno mijenja svijet. Tu je ulogu morala preuzeti Partija koja mora educirati i voditi mase izgubljene u "pogrješnoj svijesti" i nesposobne da se brinu same za sebe. Diktaturu proletarijata, dakle, treba zavesti Komunistička partija, ali i unutar Partije mora postojati jezgra (Centralni komitet) koji usmjerava partiju i održava njezinu gorljivost.

Potrebno je ukazati na još jednu važnu i bitnu posljedicu komunističkih temeljnih postavki ateizma i klasne borbe, a to je poimanje etike i morala. Osim ateizma i klasne borbe, poništenje moralnosti posljedica je Marxove i Engelsove radikalne relativnosti; nema istine i nema laži - sve može biti i ovako i onako. ${ }^{17}$ Ako nema duha, ako nema Boga, ako nema transcendencije, nema ni apsolutnoga morala, ako nema apsolutnoga dobra, put je otvoren prema apsolutnome zlu. ${ }^{18}$ Uistinu, zbog radikalnoga materijalizma i ateizma te zbog ideje klasne borbe kao pokretača povijesti, komunizam je morao završiti u nijekanju moralnosti i morala i otvoriti put u zločinjenje, nerijetko izuzetno brutalno. Lenjin je u govoru na Trećemu sveruskom kongresu Ruske lige mladih komunista 2. listopada 1920. objasnio da komunisti odbacuju etiku i moral, jer ne vjeruju u Boga. Naime, bio je uvjeren da buržoazija izvodi etiku i moral iz Božjih zapovijedi, a kako komunisti "ne vjeruju u Boga" i, k tome, "znaju" da kler i

15 Centralni komitet KPSS naredio je 24. siječnja 1919. da Kozaci budu "iskorijenjeni i fizički likvidirani svi do jednog", A. DE Benorst, Komunizam i nacizam, str. 47.

16 [Vilko Rieger], "Karl Marx o - Hrvatima", u: Hrvatska smotra, sv. II., 1934., str. 14-16.

17 Friedrich Engels, Ludwig Feuerbach i kraj klasične njemačke filozofije, Zagreb, 1947.

18 Uputa o nekim aspektima "Teologije oslobođenja", str. 31. 
buržoazija govore o Bogu samo radi svojih izrabljivačkih interesa, ne prihvaćaju ni etičke i moralne norme. ${ }^{19}$ Komunistički ideolozi svode etiku i moral na odnose među klasama, što znači na isključivo materijalni uzrok. Stoga je u istome govoru Lenjin mogao reći: "Mi kažemo da je naš moral potpuno podređen interesima klasne borbe proletarijata. Naš je moral izveden iz interesa klasne borbe proletarijata". ${ }^{20} \mathrm{~S}$ time u vezi korisno je podsjetiti na često citirani tekst iz Crvenoga mača (Krasnji Meč) 1919., glasila koje je izdavala po zločinima poznata sovjetska tajna služba Čeka: ${ }^{21}$ "Naš moral nema prethodnice i naša humanost je apsolutna jer počiva na novome idealu. Naš je cilj razoriti svaki oblik ugnjetavanja i nasilja. Nama je sve dopušteno, jer mi smo prvi koji dižemo mač ne da bismo podčinili rase i učinili ih robovima, nego da bismo oslobodili čovječanstvo njegovih veriga ... Krv? Neka krv teče kao voda. Neka krv zauvijek zaprlja barjak crnoga pirata koju vijori buržoazija i neka naš barjak bude zauvijek okrvavljen". ${ }^{22}$

U svojoj knjizi o osnivanju prve sovjetske tajne policije Čeke 1917., Martin Ivanovič Lazis (1888. - 1938.) svjedoči da je ta služba bila osnovana kada se pojavila opasnost za vlast Sovjeta. U njezinu imenu stajala je naznaka da joj je zadaća sprječavanje kontrarevolucije i sabotaže. Njezini čelni ljudi (Feliks Dzeržinski, Ivan Ksenofontovič Ksenofontov, Vasilij Kuzmič, K. A. Peterson, Jakov Kristoforovič Peters, D. G. Jevsejev i Valentin Andrejevič Trifonov) istaknuli su da su njezine zadaće spriječiti i najmanje naznake kontrarevolucije i primijeniti najdrastičnije mjere tako da svi potencijalni prekršitelji znaju da se o njima sve zna i da će biti najdrastičnije kažnjeni za najmanje

19 Dijelovi Lenjinova govora dostupni u prijevodu na engleski, na: http://leninist. biz/en/1962/CM206/Lenin-The.Tasks.of.the.Youth.Leagues

20 Pravda br. 221, 222 i 223, od 6. i 7. listopada 1920., str. 5; http://marx.org in 1997, marxists.org 1999.

21 Čeka ("Črezvičajnaja komisija" - Izvanredno povjerenstvo) naziv je za tajnu policiju u vrijeme uspostave Sovjetskog Saveza. Čeku je osnovao Vladimir Ilič Lenjin dekretom iz prosinca 1917. Za prvoga ravnatelja postavljen je bio Feliks Dzeržinski. Čeka je bila glavno oružje u borbi protiv stvarnih i izmišljenih političkih protivnika Lenjinove politike. Pogubila je između 100 i 250 tisuća ljudi iz svih slojeva ruskoga društva: aristokrata, radnika, seljaka, umjetnika, svećenika itd. Čeka se 1922. transformirala u novu tajnu službu GPU (Gosudarstvenoe političeskoe upravlenie - Gospodarsko-politička uprava), a kasnije će iz nje redom nastajati NKVD, NKGB, MGB i KGB.

22 Citat se može naći na različitim internetskim stranicama; moj prijevod s engleskoga. 
naznake proturevolucionarne aktivnosti i ponašanja. ${ }^{23}$ Odmah nakon osnivanja Čeke, Trocki je izjavio: "U manje od tjedan dana teror će poprimiti vrlo nasilnički oblik, poput onoga koji se dogodio za vrijeme Velike Francuske revolucije". Boljševička je revolucija uvelike nadmašila osude na smrt carske Rusije, jer dok je između 1825. i 1917. carski režim dosudio 6321 smrtnu presudu, Lenjinov je režim, nakon samo pet mjeseci vlasti u ožujku 1918. pobio već 18.000 osoba. Lenjin je 26. lipnja 1918. pisao Grigoriju Jevsejeviču Zinovjevu (rođenjem Hirsch Apfelbaum: 1883. - 1936.): "Kada se prijeđe na djela, valja odlučno udariti masovnim nasiljem i nad sovjetskim zastupnicima". ${ }^{24}$

Boljševički vođe osnovali su i prve logore. Upravitelj Čeke, Feliks Edmundovič Dzeržinski (1877. - 1926.), naredio je 31. kolovoza 1918. deportaciju "svakog pojedinca koji se usuđuje i na najmanju promidžbu protiv sovjetskog režima". Dekret kojim se pokreće stvaranje koncentracijskih logora objavljen je 10. rujna 1918. u listu Izvestia. Trocki je objašnjavao da se "pitanje kome će pripasti vlast neće otkriti u člancima Ustava, već uporabom svih oblika nasilja". Godine 1921. već je bilo sedam koncentracijskih logora u kojima su uglavnom bile žene i starci. Njih 65 izbrojano je 1923., kada je već ubijeno gotovo dva milijuna protivnika. ${ }^{25}$

Kolikogod se navedene izjave zbog količine i intenziteta brutalnosti čine nevjerojatnima i kolikogod izgledale kontradiktorne, one vrlo dobro oslikavaju i komunistički svjetonazor i politički program. Humanost, čovjekoljublje, po definiciji je izraz poštovanja i ljubavi, a nikako okrenuto nasilju i prolijevanju krvi. "Oslobađanje čovječanstva njegovih veriga" po definiciji ne može biti u potpunosti dovršeno u povijesti te "dizanje mača" i prolijevanje krvi, i to "u potocima", može biti samo sebi svrhom, što je komunizam dosljedno i opetovano dokazivao. Apsurd je veći po tome što su vođe boljševičke revolucije, a kasnije će to biti osobina svih komunističkih revolucija, svoje provođenje "najdrastičnijih mjera" i najbrutalnijega nasilja prikazivali kao ostvarivanje povijesne pozitivne uloge. Već spomenuti autor članka o osnivanju Čeke izjavljivao je: "Ne ratujemo mi protiv bilo koje osobe posebno. Iskorjenjujemo buržoaziju kao klasu. Ne tražite u istrazi

23 Martin Latsis, "Two Years of Struggle on the Internal Front in 1920.", https:// alphahistory.com/russianrevolution/latsis-formation-of-cheka-1920/

24 A. DE Benoist, Komunizam i nacizam, str. 42.

25 Isto, str. 42-43. 
dokumente i dokaze o onome što je optuženi počinio (...) Prvo pitanje koje mu valja postaviti jest kojoj klasi pripada". ${ }^{26}$

Kada se marksizam ogoli do svoje srži, pokazuje se kao simplificirana doktrina čija primjena nužno proizvodi radikalnu arbitrarnost i uništenje mnogih. Tumačenje svijeta rezervirano je za one koji ga revolucionarno, tj. nasilno, mijenjaju. Tako promijenjen svijet podložan je, dakako, novoj ocjeni i to ponovo onih koji su pozvani revolucionarno ga mijenjati. Tu je korijen i logično opravdanje Lenjinove teze da revoluciju vode osviješteni intelektualci, ali i među njima samo oni koji ispravno shvaćaju njezine dosege i nužnost njezina daljnjega provođenja. Tu smo u začaranome krugu koji nužno dovodi do diktature, ne klase proletarijata nego uskoga kruga svjesnih revolucionara i u konačnici do jednoga jedinog Diktatora.

\section{Odnos marksizma prema religiji i kršćanskim Crkvama}

Istaknimo samo ono što su komunistički priznati autoriteti rekli o njihovu odnosu prema religiji i kršćanskim Crkvama. Osim teoretskih, za njih postoje dva praktična razloga zbog kojih se otvoreno bore protiv religije. Bore se protiv Crkve koja propovijeda nauk koji oni smatraju propagandom za držanje masa u neznanju i vjerskom ropstvu, a drugi razlog je taj što je zbog toga djelovanja Crkve među radništvom prisutna velika količina predrasuda. ${ }^{27}$ Ono što je zanimljivo jest to da komunistički teoretičari nisu ignorirali činjenicu da se buržoazija borila protiv religije, a da oni dovršavaju ono što je ona započela, ali nije privela kraju. Zato komunisti primjenjuju drastične mjere kako bi onemogućili Crkvu da provodi kontra-revoluciju. Pod parolom razdvajanja Crkve i države, komunisti su oduzeli Crkvi sav imutak i oplijenili sve zaklade. ${ }^{28}$

Uistinu, u državama u kojima je vladala marksističko-lenjinistička ideologija odnos prema religiji i kršćanskim Crkvama nije ostao samo na izraženu ateizmu, nego je poprimio izričite protuvjerske naboje koji su narasli do mržnje i fizičke eliminacije vjernika i religijskih ustanova i struktura. No, i mržnja i svjesno poticanje na nju ima

26 Citirano u: A. De Benoist, Komunizam i nacizam, str. 47.

27 Nikolai Ivanovich Bukharin - Yevgeni Alekseyevich PreobrazhenSKY, "The ABC of Communism", https://www.marxists.org/archive/bukharin/works/1920/abc/11.htm

28 Isto. 
svoje izvorište u zahtjevu za revolucionarnim mijenjanjem svijeta, jer je ono ostvarivo brutalnom eliminacijom buržoazije. Raspirivanje mržnje pripravni je čin radikalnoga uništenja buržoazije. Lenjin je bio svjestan toga kada je 1922. godine svoje protivnike izjednačavao sa životinjama. Naime, ako uvjeriš rulju da su "neprijatelji" životinje, i to one najgrđe, cilj uništenja tih je osiguran. Manualni radnik koji je postao utjecajan marksistički pisac, Maksim Gorki (rođenjem Aleksej Maksimovič Pješkov: 1868. - 1936.), u tome je bio još izričitiji: "Klasna mržnja mora se njegovati organskim odbijanjem neprijatelja, kao nižega bića. Osobno sam uvjeren da je neprijatelj doista inferiorno biće, izrod u tjelesnom, ali i u moralnom smislu". ${ }^{29}$

Komunisti su iskazivali obilje mržnje prema kršćanstvu. U vrijeme proturevolucije u Rusiji i suočen s prosvjedima vodstva pravoslavne Crkve, Lenjin je odlučio upotrijebiti nametnutu glad za konačno uništenje Ruske pravoslavne crkve. Krajem veljače 1922. vlada je objavila dekret kojim se Crkvi oduzimaju sve dragocjenosti i stavljaju $\mathrm{u}$ fondove Centralne komisije za pomoć gladnima. ${ }^{30} \mathrm{U}$ pismu članovima Politbiroa 19. ožujka 1922., objašnjavajući iskoristivost pobune pravoslavnih vjernika i svećenstva u Suji za financijsko osnaženje Partije, Lenjin je poručivao: "Mi moramo, kolikogod to koštalo, prisvojiti to blago od nekoliko stotina milijuna zlatnih rubalja (možda čak i nekoliko milijardi!). Sve se to može uspješno ostvariti samo sada. [...] Zato, dolazim do kategoričkog zaključka da je došao čas za najodlučnije i najnemilosrdnije uništenje najcrnjega svećenstva, $s$ takvom brutalnošću da se toga sjećaju desetljećima". ${ }^{31}$ Lenjin zatim daje prijedlog praktične izvedbe plana i ističe da je cilj "pogubljenje i strijeljanje izvjesnog broja svećenika". Lenjin je zaključio svoje pismo riječima: "Śto veći broj predstavnika reakcionarnog svećenstva i reakcionarne buržoazije bude pogubljen, to bolje za nas. Moramo smjesta dati lekciju svim ljudima te vrste da više desetljećima ne pomisle na bilo kakav otpor". 32

29 Citirano u: A. De Benoist, Komunizam i nacizam, str. 47.

30 N. Werth, "Država protiv svojeg naroda", str. 132.

31 Isto, str. 133.

32 Isto, 134. Crkveni izvori govore o 2691 svećeniku, 1962 redovnika (kaluđera) i 3447 redovnica, ubijenima tijekom 1922. godine. 


\section{Jugoslavenski komunisti prema vjernicima i službenicima u Katoličkoj Crkvi}

Stanje u kojem se našla Katolička Crkva neposredno nakon rata opisali su hrvatski katolički biskupi u svojoj poslanici vjernicima 20. rujna $1945 .{ }^{33}$ Odmah nakon preuzimanja vlasti komunisti su zabranili sve katoličke organizacije, ukinuli su sve odgojno-obrazovne i karitativno-humanitarne ustanove u okrilju crkvenih redova, mnogi samostani časnih sestara, kao i biskupijske i župne zgrade, djelomice ili u cijelosti oduzete su i dane na korištenje drugima, vjerska pouka bila je dopuštena samo u crkvenim prostorima, agrarnom reformom te konfiskacijom i nacionalizacijom Crkvi je oduzet velik dio zemljišta i drugih posjeda, a svećenici na župama opterećivani su prekomjernim porezima, većina škola i učilišta za spremanje svećeničkih kandidata bila je zatvorena ili pred zatvaranjem, zabranjen je gotovo sav vjerski tisak. Uveden je sustav doušništva, tako da su svi svećenici bili pod neprestanom paskom.

Najveći je problem bilo masovno i sustavno ubijanje svih koji su bili percipirani kao mogući protivnici komunističkome sustavu. Srž politike Komunističke partije Jugoslavije bilo je svrstavanje svih nekomunističkih stranaka, političkih opredjeljenja, ideologija i vjerovanja - ukratko, svih koji nisu bili na njihovoj strani - u kategoriju "narodnih neprijatelja" prema kojima treba primijeniti najoštrije mjere osvete i fizičke eliminacije. ${ }^{34} \mathrm{U}$ tomu im je na ruku išla i politika Saveznika prema neprijateljskim vojskama. Još tijekom rata, u Londonu je 20. listopada 1943. ustanovljena Međunarodna komisija za ratne zločine, a sve su saveznice bile potaknute na osnivanje svojih nacionalnih komisija. Antifašističko vijeće narodnog oslobođenja Jugoslavije (AVNOJ) ustanovilo je Zemaljsku komisiju za ratne zločine (ZKRZ) već 30. studenoga 1943. Odmah nakon rata, bile su ustanovljene komisije na razini mjesta, općina i kotareva, tako da ih je u jeku njihovih aktivnosti u Jugoslaviji bilo 1574. Utjecajni ljudi u komisijama, mahom članovi Partije, nerijetko su krojili optužnice po

33 Ivan Mužić, Pavelić i Stepinac, Split, 1991., str. 161-175; Juraj Batelja, Blaženi Alojzije Stepinac - svjedok Evandelja ljubavi, knj. I.-III., Zagreb, 2010., knj. III., str. 253-279.

34 Dušan Bilandžıć, Historija SFRJ, Zagreb, 1985., str. 52; LeON GeršKović, Dokumenti o razvoju narodne vlasti, Beograd, 1948. (Zagreb, 1983.), str. 266; ZAVNOH, zbornik dokumenata 1945., Zagreb, 1985., str. 304. 
mjeri osobnih razmirica, zlopamćenja, zavisti, osvete i ideoloških i/ ili političkih očekivanja. ${ }^{35}$

Jugoslavenski komunisti uspostavljali su i druge institucionalne poluge za uništenje "narodnih neprijatelja". Osvajanjem većih teritorija tijekom rata, osnivali su "narodnu vlast" formaliziranu u "Narodnim odborima", u kojima je Komunistička partija imala potpunu kontrolu. Prema uzoru organizacija u Sovjetskom Savezu, Josip Broz, zvani Tito u Drvaru je 13. svibnja 1944. potpisao dokument o osnivanju Odjeljenja za zaštitu naroda (OZN-a) kao obavještajne i kontraobavještajne službe, koja je trebala igrati glavnu ulogu u pronalaženju i eliminiranju "narodnih neprijatelja". ${ }^{6}$ Toj su obavještajnoj agenciji pridodane i vojne postrojbe Korpusa narodne obrane Jugoslavije (KNOJ), što je uvelike osnažilo njezinu represivnu učinkovitost. U isto vrijeme, 24. svibnja 1944., uspostavljeni su i Vojni sudovi, koji su komunistima služili za kakvo-takvo legalističko pokriće procesa eliminacije "narodnih neprijatelja". ${ }^{37}$ Tako ustrojen represivni institucionalni sustav bio je ojačan sustavom doušništva, uhićenja, zatvora, logora, suđenja, osvetničkih kažnjavanja te pojedinačnih i masovnih likvidacija bez ikakvih suđenja. ${ }^{38}$

Nakon završetka rata, tako ustrojen represivni sustav bio je moćno sredstvo u rukama Komunističke partije Jugoslavije s kojim je mogla uspostaviti posvemašnju kontrolu nad političkim procesima te eliminirati ili onemogućiti bilo kakvu oporbu. Obračunala se s pripadnicima vojnih formacija hrvatske vojske (Hrvatskih oružanih snaga, sastavljenima od domobrana i ustaša) te mnogobrojnim civilima koji su se zajedno s vojskom povlačili prema područjima koja su već bila u rukama Saveznika, a oni ih na prijevaru vratili partizanima/komunistima. Zatim je preko mnogobrojnih komisija za ratne zločine ubila ili zatvorila mnoge neistomišljenike, a osnivanjem logora započela "idejni preodgoj". Samo tijekom ostatka 1945. godine

35 Zdenko Radelić, Hrvatska u Jugoslaviji 1945. - 1991., Zagreb, 2006., str. 56-71.

36 Vidi: William Klinger, Teror narodu. Povijest Ozne, Titove političke policije, Zagreb, 2014., str. 107-112; JosIP JuRČEvić, Bleiburg. Jugoslavenski poratni zločini nad Hrvatima, Zagreb, 2005., str. 241.

37 Partizanska i komunistička represija i zločini u Hrvatskoj 1944. - 1946. Dokumenti, ZdRAvko Dizdar i dr. (prir.), Slavonski Brod, 2005., dok. br. 1, str. 35-42.

38 Vidi: "Predgovor", u: Partizanska i komunistička represija, ZDRAVko DizDAR i dr. (prir.), str. 15-22; J. JuRČEvić, Bleiburg. Jugoslavenski poratni zločini, str. 302-338. 
nakon završetka rata, Vojni sudovi izrekli su 5484 smrtne kazne. ${ }^{39}$ Sve je to obavljeno u ozračju straha i nesigurnosti, dodatno poticanima sveprisutnom propagandom. ${ }^{40}$ Crkva je obično prikazivana kao "profašistička", "klero-fašistička", "protunarodna" i "reakcionarna". Dosljedno, viša crkvena hijerarhija i kler optuživani su za suradnju s okupatorom, za širenje mržnje i nesloge među narodima i vjerama te za poticanje i sudjelovanje u ratnim zločinima. ${ }^{41}$ Osvrćući se na osude svećenika na kaznu smrti, katolički je episkopat 20. rujna 1945. u poslanici vjernicima istaknuo da je "poštena i nepristrana javnost u pravu, da osporava ovim smrtnim osudama svećenika najbitniju vlastitost sudske presude, a to je pravednost". ${ }^{42}$ Biskupi su zanijekali komunistima da su takvo sudovanje i takve osude vršene "u ime naroda": "Nespojivo je naime s naravnim kršćanskim osjećajem pravde, koji je vrlo budan u našim vjernicima, da se izriče smrtna osuda zato, što je netko drugoga političkog mišljenja, a nije inače počinio nijednog drugog zlodjela". ${ }^{43}$ Biskupi nisu digli svoj glas samo zbog svećenika, nego i zbog "drugih tisuća i tisuća, vaših sinova i vaše braće, koji su kao i oni osuđeni na smrt, a da nisu mogli dati svoje obrane, kako je dozvoljava svaka kulturna država".44

39 Vladimir Geiger, "Žrtve i mučenici Drugoga svjetskog rata i poraća u Hrvatskoj", u: Hrvatski mučenici $i$ žrtve iz vremena komunističke vladavine. Zbornik radova s međunarodnog znanstvenog skupa održanog u Zagrebu 24. i 25. travnja 2012. godine, Zagreb, 2013., str. 107-126 (119).

40 BiLjana Kašıć, "Značajke partijske ideologije u Hrvatskoj (1945. - 1948.)", u: Časopis za suvremenu povijest, 23/1991., br. 1-3, str. 246; KATARINA SPEHNJAK, "Uloga novina u oblikovanju javnog mnijenja u Hrvatskoj 1945. - 1952.", u: Časopis za suvremenu povijest, 25/1993., br. 2-3, str. 166; IDEM, Javnost i propaganda. Narodna fronta u politici i kulturi Hrvatske, Zagreb, 2002.; BERISLAV JANDRIĆ, "Tisak totalitarne komunističke vlasti u Hrvatskoj u pripremanju montiranog procesa zagrebačkom nadbiskupu Alojziju Stepincu (1946.)", u: Croatica christiana periodica, 47, 2001. Za područje Šibenske biskupije i Zadarsku apostolsku administraturu, vidi: ANTE SKračIĆ, "Šibenska biskupija u poraću do smrti biskupa Banića", u: Sedam stoljeća Šibenske biskupije. Zbornik radova sa znanstvenog skupa Šibenska biskupija od 1298. do 1998., Šibenik, 2001., str. 463-480.

41 Dokumenti o protunarodnom radu i zločinima jednog dijela katoličkog klera, JožA Horvat - Zdenko ŠTAmbuK (prir.), Zagreb, 1946.; VikTor NovaK, Magnum crimen. Pola vijeka klerikalizma u Hrvatskoj, Zagreb, 1948.

42 Pastirsko pismo katoličkih biskupa Jugoslavije, izdano s općih Biskupskih konferencija, Zagreb, 20. rujna 1945., citirano, u: Juraj Batelja, Blaženi Alojzije Stepinac svjedok Evandelja ljubavi, knj. III., str. 270.

43 Isto, str. 270-271.

44 Isto, str. 271. 
Suđenja su u jednakoj mjeri bila usmjerena na slanje poruke građanstvu o novim temeljnim vrijednostima i vjerovanjima te o posljedicama za one koji ih ne prihvate ili odbace. Te uvide potvrđuju formulacije u optužnicama koje se ponavljaju poput mantre. Optuženi su proglašavani krivima mahom za slabljenje "narodnooslobodilačke borbe" ili vojske, koja se bori za "bratstvo i jedinstvo" jugoslavenskih naroda, te za suradnju s neprijateljem, te da je također njihovo djelovanje usmjereno na slabljenje "narodnooslobodilačke borbe". Manje-više svi su bili proglašavani izdajicama (kvislinzima), narodnim neprijateljima, kolaboracionistima i sl. Komunističke vlasti u Jugoslaviji primijenili su i postupak prema svojim neprijateljima za koji su katolički biskupi primijetili da je "neobičan", a to je da su s grobova ustaša i njemačkih vojnika poskidale križeve i sva druga obilježja te grobove sravnile sa zemljom do brisanja svakoga traga njihova postojanja. ${ }^{45}$

Iznimno je zanimljivo i znakovito kako su jugoslavenski komunisti pisali o zločinima sovjetske Crvene armije na području Srbije 1944. godine. Evo početka jednoga članka (u izvornoj verziji): "Riječ će biti o amoralnim i zločinačkim postupcima pripadnika Sovjetske armije, od časa njihovog stupanja na tle Jugoslavije pa do odlaska. Po divljaštvu, primitivizmu i nekulturnosti, takvi postupci su prevazišli sve do sada poznate u istoriji i daleko su za sobom ostavljali vojnike Ivana Groznog, Petra Velikog i druge. I fašističke, svakako".46 $\mathrm{Au}-$ tor je bio major Jugoslavenske narodne armije. Naravno, to je bilo objavljeno 1953., u vrijeme kada je u Titovoj Jugoslaviji još vladala ljutnja zbog Staljinova isključenja Jugoslavije iz komunističkoga bloka. Vrijedno je istaknuti i objašnjenje toga ponašanja: "Ovdje su u pitanju masovna zločinstva, čitav jedan sistem ratne kriminalistike, rijetkosti u međunarodnom ratnom pravu... I što je najvažnije, sve se to čini pod firmom socijalizma, s pozivanjem na Lenjina i Oktobar; sve se to vrši u ime - proletarijata!"47 Titovi vojnici se zasigurno nisu ništa drukčije ponašali.

45 Isto, str. 276.

46 Radivoje Jovanović, Ubijeni ljudski obziri: zločinstva crvenoarmejaca u Jugoslaviji, Sarajevo, 1953., str. 7.

47 Isto, str. 16. 


\section{Umanjivanje zločinačkoga svojstva komunizma i relativizi- ranje komunističkih zločina}

Unatoč nedvojbenim teoretskim postavkama marksističko-lenjinističke doktrine i velikoga broja zločina komunističkih vlasti na svim područjima na kojima je bila uspostavljena, lijevo orijentirana intelektualna elita na Zapadu nije problematizirala tu ugrađenu sklonost komunizma na zločinjenje. Tek nakon pada komunizma u Sovjetskom Savezu i istočnoeuropskim zemljama započela je diskusija, i polemika, o zločinačkoj naravi komunizma i o usporedbi u tom smislu komunizma s nacionalsocijalizmom. Tomu je mnogo pridonijelo objavljivanje knjige Crna knjiga komunizma u Francuskoj, koja je prevedena na mnoge jezike. ${ }^{48}$ Njezin se utjecaj dijelom može pripisati činjenici da ju je uredio bivši maoist Stéphane Courtois, što sugerira da joj se sadržaj ne može pripisati možebitnoj tendencioznosti tradicionalno protukomunistički raspoloženih pisaca. Valja ipak istaknuti da se morao ispuniti taj uvjet kako bi kritika komunizma i njegovo uspoređivanje s nacizmom postalo "dozvoljeno". Knjiga je potaknula rasprave i polemike ponajprije među francuskim intelektualcima što je imalo velik odjek, budući da je upravo u Francuskoj postojala jaka filo-komunistička intelektualna tradicija, koja je žestoko udarila na samu tezu da su nacionalsocijalizam i komunizam usporedivi glede počinjenih zločina. Filo-komunisti su upotrebljavali argument, koji se kasnije mogao čuti i u Hrvatskoj, da je komunizam po svojim intencijama humanizam, koji je krenuo po zlu, dok je nacionalsocijalizam zlo u svojoj intenciji. ${ }^{49}$ Njihovi su argumenti višeslojni, od toga da je komunizam od početka privlačio ljude zbog ideala zajedništva, jednakosti među ljudima - dakle, humanizma, do toga da njegovi zločini

48 Stéphane Courtois et al., Le livre noir du communisme - Crimes, terreur, répresion, Paris, 1997. U zemljama bivše Jugoslavije objavljeni su prijevodi u Hrvatskoj (Crna knjiga komunizma - zločini, teror, represija, Zagreb, 1999.) i u Bosni i Hercegovini (Crna knjiga komunizma - zločin, teror, represija, Sarajevo, 1999.). Iscrpan i vrlo dobar prikaz knjige objavio je i prije prijevoda na hrvatski Neven Śmac, "Crna knjiga komunizma", u: Crkva u svijetu, 33/1998., br. 3, str. 276-294. Prikaz te knjige objavio je također Juraj Batelja, "Značenje i poruke 'francuske' i 'hrvatske' Crne knjige", u: Juraj BATElja (prir.), Crna knjiga o grozovitostima komunističke vladavine u Hrvatskoj, Zagreb, ${ }^{2} 2000$., I. dio, str. VII.-XXV. Iz toga je jasno da je u poslijeratnoj Hrvatskoj, vjerojatno 1946., objavljena knjižica nepoznatog autora s naslovom Crna knjiga, vidi: Isto, str. 1-51.

49 Opširnije: A. DE Benoist, Komunizam i nacizam, str. 33 i dalje. 
nisu bili od početka predvidljivi, dok je nacizam motiviran mržnjom i njegovi su zločini bili predvidljivi. ${ }^{50}$ Prema tim teorijama, Staljinovi zločini predstavljaju perverziju komunizma, dok su Hitlerovi izravna posljedica nacističke ideologije, zadojene mržnjom; nacizam je po naravi zločinački, dok je to marksizam grješkom, zato što je nešto pošlo ukrivo. Takva se opravdanja propagiraju unatoč priznanju da su posljedice komunističke diktature više od 100,000.000 mrtvih.

Odgovor na takve argumente sadržan je u izreci da je dobrim nakanama popločan put u pakao. Protiv je svake razumske logike argument da je ubijanje s dobrom nakanom, pa i onda ako se tvrdi da je to zbog boljitka svijeta, opravdano ili manje zlo od ubijanja s jasnom nakanom da se to želi. Štoviše, veći je zločinac onaj koji tvrdi da čini zločine radi visokih ideala od onoga koji je žrtva pogrješne savjesti. Tako je veća odgovornost onih koji obećavaju dobro, svijetlu budućnost, nestanak klasnih razlika i sl., a siju oko sebe smrt. I Crkva je danas svjesna da je veći grijeh onih koji propovijedaju Radosnu vijest i pri tome nanose zlo nemoćnima i nebranjenima, nego onih koji svoje postupke ne umataju u dobre nakane.

Filo-komunisti i nekadašnji članovi komunističkih partija nude varijacije na te argumente. No, iz onoga što je ovdje obrazloženo, ne može se govoriti o marksizmu kao o humanističkom projektu koji je u nekom trenutku, zbog vanjskih okolnosti, otišao ukrivo, nego je nasilje ugrađeno u sam sustav kao neizostavan čimbenik. Ne može se govoriti o dobrome Lenjinu i zločestome Staljinu u smislu da je Staljin iskrivio Lenjinov nauk, jer je u sam sustav koji je pokretao i jednoga i drugoga ugrađeno nasilje i zločin. ${ }^{51}$

Osim toga, ideje komunističkoga besklasnog društva i nacističke čiste rase kvalitativno su iste utopijske zablude koje nastoje ostvariti ideološke ciljeve eliminacijom "loših" klasa i "loših" rasa. ${ }^{52}$ Ponovo je jasno da je zločin u temeljima komunističke ideologije. Kao što smo vidjeli, u tome su Marx i Engels bili izravni: "njihovi se ciljevi mogu postići samo nasilnim obaranjem čitavog dosadašnjeg društvenog poretka". 53

50 Isto, str. 33-34.

51 Isto, str. 42 ss.

52 Isto, str. 46-47.

53 K. Marx - F. Engels, Manifest komunističke partije, Marksistički centar, Split, ${ }^{2} 1975$. 
Također smo vidjeli kako je Lenjin preporučivao vješanje bogatih seljaka (kulaka) kao primjer drugima. ${ }^{54}$

Iako su se mnogi zaustavljali na promatranju marksizma kao napora za mijenjanje svijeta, štoviše za razrješenje nekih njegovih nedostataka, poput nemogućih uvjeta radničkoga života, previđalo se - namjerno ili nenamjerno, nije toliko važno - da je to pokušaj na apsolutan način, tj. putem uništenja predmnijevana uzročnika zla u svijetu.

Ima među komunistima i njihovim suputnicima pokušaja da se nasilje koje je pratilo sva komunistička nametanja vlasti od sovjetske proturevolucije u Rusiji do danas objašnjava ratnim ili nekim drugim izvanjskim okolnostima. ${ }^{55}$ Komunisti bivše Jugoslavije svoje nasilje opravdavali su, i danas ga još opravdavaju, štoviše hvale, time što tvrde da je bio odgovor na ustaško nasilje. I autori Crne knjige komunizma posezali su za tradicijom ropstva i nasilja u Rusiji kako bi objasnili izvor tako velika i sveobuhvatna komunističkoga terora. ${ }^{56}$

No, ako se dobro razumije logika komunističkoga svjetonazora, nasilje, i to obilno, njegov je logičan ishod.

Bivši komunisti i filo-komunisti nisu zasigurno posvećivali nimalo pozornosti analizi komunističke ideologije nekoliko Papa, napose enciklici pape Pija XI. Divini Redemptoris od 19. ožujka 1937. koja je bila upravljena upravo onima koji su se zanosili komunizmom. Papa je u svjetlu katoličkoga nauka i filozofske tradicije ukazao na bitna svojstva komunističke ideologije i upozorio na to da komunizam primjenom nasilja nadvisuje sve dotadašnje progone protiv Crkve.

U podlozi komunizma, iznosi Papa, leži ideja lažnoga spasenja, koje bi trebalo ostvariti pseudo-ideal pravednosti, jednakosti i bratstva u radu. S druge strane, u komunističkoj ideologiji prisutan je svojevrstan pogrješan misticizam, koji zavodi i zanosi mnoštvo varavim obećanjima. ${ }^{57}$ Središnja teza Papine enciklike jest u tome da je ko-

54 N. WERTH, "Država protiv svojeg naroda", str. 40-279 (80); autor se referira na Državni arhiv Ruske Federacije.

55 Za raspravu o objašnjenju nasilja kao odgovor na povijesne prilike, vidi: A. DE BenoIst, Komunizam i nacizam, str. 41-44.

56 N. ŠımaC, "Crna knjiga komunizma", str. 285.

57 Encikličko pismo pape Pija XI. "Divini Redemptoris" o bezbožnom komunizmu, u: Katolički list, Zagreb, 88/1937., br. 14, str. 161-164; br. 15, str. 173-177; br. 16, str. 185-186; br. 17, str. 197-199 i br. 18, str. 209-212; (dalje: Divini Redemptoris i br. u enciklici na koji se bilješka odnosi) ovdje br. 8 . 
munistička ideologija na kojoj se temelji njegovo djelovanje protivna naravnome zakonu, onomu što zdrav ljudski um zaključuje, ako nije iskvaren kojekakvim pogrješnim i lažnim pretpostavkama, poput onih na kojima počiva ta ideologija. U komunizmu je ponajprije pogrješna slika o čovjeku: "[...] komunizam čovjeka lišava njegove slobode, duhovnoga osnova moralnog djelovanja". ${ }^{58} \mathrm{Iz}$ toga slijedi lišavanje ljudske osobe dostojanstva, prirodnih prava, prirodno postojanje hijerarhijskih odnosa među ljudima i stvarima i postojanje autoriteta, postojanje privatnoga vlasništva i sl. ${ }^{59}$ Umjesto privatno zagovara se kolektivno vlasništvo i rad za zajednicu, a - kako je to protiv ljudske prirode - vlast bi imala prava prisiliti radnike i sve druge osobe da rade u smislu tih ciljeva. ${ }^{60}$

Ukratko, Papa zaključuje da komunizam nudi neko novo "evanđelje" za spas i izbavljenje, dok zapravo nudi "sustav, pun pogrešaka i sofizama, koji je u suprotnosti i sa razumom i sa božanskom objavom", komunizam nudi sustav koji "ne priznaje pravo podrijetlo prirode i cilj države, koji negira prava ljudske osobe, njegovo dostojanstvo i slobodu".61 Za razliku od liberalizma koji je prethodio i pripravio put komunizmu, komunizam je otvoreno protiv "svemu onome što je božansko" (2 Sol 2,4) pri tome po prvi put u povijesti primjenjuje razna sredstva prisile i zločina. ${ }^{62}$

Papa je odgovorio i na pitanje koje se postavlja još i danas, a to je zašto je komunizam ipak privlačan i zavodljiv. To je zato što nudi laka i prijeka rješenja, uz prešućivanje stvarnih ciljeva i metoda njihova postizanja. ${ }^{63}$ Hrvatski katolički pisci i aktivisti između dva svjetska rata kratko su zaključili da je riječ o prijevari, u koju se lako upadne i kasnije teško priznaje. ${ }^{64}$

58 Divini Redemptoris, br. 10.

59 Isto.

60 Isto, br. 11.

61 Isto, br. 14.

62 Isto, br. 22-23.

63 Isto, br. 15 i drugdje.

64 Među inima, spominjem sljedeće autore: Franjo ŠAnC, D.I., "Na izvorima dijalektičkog materijalizma", u: Život, 18/1937., br. 9-10, str. 420-433; IvAN KoRSKY, "Katolička crkva kao historijska činjenica pobija dijalektički historijski materijalizam", u: Život, 18/1937., br. 9-10, str. 444-451; DR. O.[TON] KNEZOvić, "Kriza ruske crkve", u: Katolički list, br. 51, 23. 12. 1926.; Dr. N.[IKolA KolareK], "Previranja i krize borbenog ateizma", u: Katolički list, br. 16, 18. 
Marksističkom idejom o klasnoj borbi nerijetko su bili oduševljeni i površni teolozi, primjerice zagovornici "teologije oslobođenja". Ne čudi stoga što im je Uputa Zbora za nauk vjere, kojoj je predsjedao hrvatski kardinal Franjo Šeper (1905. - 1981.), o teologiji oslobođenja tumačila značenje pojma klasne borbe: "Taj je pojam i danas prožet tumačenjem koje mu je dao Marks pa se dosljedno ne može smatrati istoznačnicom, koja ima samo empirički doseg za 'zaoštreni društveni sukob"'. ${ }^{65}$ Neki su teolozi mislili da mogu od marksizma preuzeti analizu svijeta i društvenih odnosa, ne prihvaćajući marksistički ateizam. Crkva je odbacila takvo stajalište, jer "U logici marksističke misli 'analiza' se ne može odvojiti od prakse i od poimanja povijesti s kojom je praksa povezana. Tako je analiza instrument kritike a kritika je pak samo jedan momenat (sic) revolucionarne borbe. To je borba klase proletarijata i ima svoje povijesno poslanje. [...] Dosljedno tome, samo onaj koji sudjeluje u toj borbi može provoditi ispravnu analizu". ${ }^{66} \mathrm{U}$ Uputi o nekim aspektima "teologije oslobođenja", vatikanski Sveti Zbor za nauk vjere ukazao je na riječi upozorenja pape Pavla VI. da se ne može izabrati marksistička analiza društvenih problema bez prihvaćanja ideologije na koju se ta analiza naslanja.${ }^{67}$ Marksistička analiza počiva isključivo i radikalno na materijalnim odnosima te ako se prihvaća ta analiza ujedno se prihvaćaju i ideološke pretpostavke na kojima počiva. Ista Uputa o "teologiji oslobođenja" prepoznaje postojanje više struja u marksizmu koje se

4. 1935.; Dr. N. K. [Nikola Kolarek], "Ofenziva Komunističke Internacionale", u: Katolički list, br. 4 do br. 15, 23. 1. 1936.; -nk- [Nikola Kolarek], "Fides intrepida", u: Katolički list, br. 6, 10. 2. 1938.; -nk- [Nikola KolareK], "Vođe francuske Pučke fronte u zatvoru", u: Katolički list, br. 48, 28. 11. 1940.; Vigilans [Ivo Lendić], "Budite budni! Stojimo pred požarom!", u: Luč, 32/1936.-37., br. 2. Za Lendićeve polemike s marksističkim piscem Miroslavom Krležom, vidi: Ivo Lendić, Katolicizam i kultura. Eseji, članci i polemike, Biblioteka Hrvatska katolička baština 20. stoljeća, knjiga 8, (ur. Božidar Petrač), Glas Koncila, Zagreb, 2008., str. 255-318; RYS [I. BogDAN], Kominterna (Komunistička internacionala), Zagreb, 1934.; Komunisti u Hrvatskoj, Zagreb, 1936.; Nova Španjolska, Zagreb, 1937.; Svjedočanstva o Rusiji, Zagreb, 1937.; Španjolska u krvi i plamenu, Zagreb, 1937. O raspravama katoličkoga tiska o građanskome ratu u Španjolskoj i o ulozi komunista, vidi: J. KRIŠTo, "Odjek građanskoga rata u Španjolskoj (1936. - 1939.) u Hrvatskoj", u: Časopis za suvremenu povijest - Spomenica dr. Jere Jareba, 40/2008., br. 3, str. 1033-1044.

65 Uputa o nekim aspektima "Teologije oslobođenja", str. 27.

66 Isto, str. 30.

67 Isto, str. 26-27. Uputa se referira na encikliku pape Pavla VI., Octogesimo adveniens, 34: AAS (1971), str. 424-425. 
međusobno znatno razlikuju, ali ne ostavlja dvojbe da "ukoliko su i dalje marksističke, one ostaju vjerne osnovnim postavkama koje su nespojive s kršćanskim poimanjem čovjeka i društva. U tom sklopu pojedine formulacije nipošto nisu neutralne, nego zadržavaju značenje što su ga poprimile u izvornom učenju marksista".

\section{Zaključak}

Iz analize riječi i djela njegovih otaca, marksizam se predstavlja kao snop obećanja o promjeni odnosa u društvu, zapaljivih slogana, nerealnih koncepcija o čovjeku i društvu te brutalan obračun s pogrješnim klasama, religijskim ljudima i organiziranim Crkvama, ukratko sa svim neistomišljenicima. Središnja preokupacija komunističkih vođa jest revolucija, mržnja i osveta, uz lažno obećanje promijenjenih i poboljšanih uvjeta života. Stoga komunizam proizvodi smrt i nevolju, jer je u svojoj biti okrenut prema zlu. On je također sustav osmišljen za ekstremnu kontrolu ljudskoga duha i propisivanja načina mišljenja.

Ishodi primijenjena komunizma očekivani su kada se ima u vidu njegove temeljne filozofske pretpostavke. Radikalan ateizam i poimanje svijeta kao odnos materijalnih datosti te poimanje društva kao predatorski odnos buržoazije i proletarijata koji se može i mora prevladati jedino revolucijom i masovnim uništenjem protivnika, neminovno proizvodi mnogo nasilja, jednom riječi zla. Odsutnost Boga i pomanjkanje potrebe razlučivanja dobra i zla također otvara vrata samouvjerenju nekolicine o svome apsolutnome autoritetu. Komunizam je u praksi uvijek izdvajao uski krug samozvanika koji je odlučivao o tome što je najbolje za one koji nisu bili dio te izabrane skupine (Partije) i koji je preventivno nastojao eliminirati potencijalne političke protivnike.

U nauku Katoličke Crkve komunizam predstavlja pogrješno poimanje čovjeka, pogrješnu koncepciju ljudskoga društva, pogrješnu analizu ljudskih odnosa i pogrješno razumijevanje povijesti. I budući da je komunizam sveobuhvatan sustav, svjetonazor, Crkva je i na službenoj razini isticala da ga ne može prihvatiti niti dijelom, nego ga mora odbaci u cijelosti.

Dolaskom na vlast u Hrvatskoj i Bosni i Hercegovini, komunisti su ponovili sve ono što su njihovi uzori, od Lenjina do Staljina, ranije radili u Rusiji. Komunizam se još jedanput potvrdio kao sustav $s$ inherentnim predispozicijama za gušenje slobode i slobodne misli i drastičan potiratelj svih unaprijed prokazanih segmenata društva. 
Stoga je razumljivo da upravo Katolička Crkva posvećuje posebnu pozornost žrtvama toga bezbožnog, nehumanog i protucivilizacijskog sustava i da njihovu žrtvu želi istaknuti kao svjedočenje za Boga, vjeru, osobne ideale, zajedništvo svetih i kao zalog za stvarnu bolju budućnost svijeta. Pomaganjem osvjetljavanja okolnosti njihova mučeništva, članovi te Crkve u hrvatskome narodu samo ispunjavaju svoj dug prema tim žrtvama. 
JURE KRIŠTO

\section{Criminal Nature of Communism}

\section{Summary}

In the word analysis and acts of its fathers Marxism is represented as a bundle of promises on the change of relations in society, flammable slogans, unrealistic conceptions of a human and society and brutal reckoning with the wrong classes, religious people and organized Churches or in short with all the dissidents. Central preoccupation of all communist leaders is revolution, hate and revenge with false promise to offer changed and improved living conditions. Thereby communism produces death and trouble, since it is turned to evil. It is also a system designed for extreme control of the human spirit and prescribing the way of thinking.

If we take into consideration its basic philosophical assumptions outcomes of the applied communism are expected. Radical atheism and considering world as a relation of material realities as well as considering society as a predatory relation of bourgeoisie and proletariat which can be and has to be overcome only by revolution and massive destruction of opponents, inevitably produce a lot of violence or evil. Absence of God and lack of need for distinguishing good and evil gives the self-confidence to a couple of people regarding their absolute authority. In practice communism always isolated a tight group of those who decided what the best was for those who were not a part of that selected group (Party) and who endeavored to eliminate potential political opponents.

As far as Catholic dogma is concerned, communism represents a wrong understanding of a man, wrong concept of the human society, wrong analysis of human relations and wrong understanding of the history. Since communism is a comprehensive system, world view, the Church officially pointed out that it could not accept it any part, it must reject it completely. 
Having come into power in Croatia and Bosnia and Herzegovina, communists repeated everything their role models, from Lenin to Stalin, had done before in Russia. Communism was confirmed one more time as a system with inherent predispositions for suppressing freedom and free ideas and as a suppressor of all in advance denounced segments of the society.

Therefore it is understandable that Catholic Church pays special attention to the victims of that godless, antihuman and anti-civilizational system and that it wants to point out their sacrifice as witnessing for God, religion, personal ideals, communion of holy persons and as a pledge for a really better future of the world. Helping to shed light on the circumstances of their martyrdom, members of that Church in Croatian people only fulfill their debt towards those victims.

Keywords: communism; ideology; class; crimes; hatred; persecution; Church; victims; martyrs. 